\title{
Islamic Economics Ethics Perspective on Economic Development in the Time of Coronavirus Disease (Covid-19)
}

\author{
Rahmad Hakim ${ }^{1, \text { a, * }}$, Muslikhati ${ }^{2, \text { b }}$, Fitrian Aprilianto ${ }^{3, \mathrm{c}}$ \\ 1, 2, 3 Department of Islamic Economics, Faculty of Islamic Studies, \\ Universitas Muhammadiyah Malang \\ Jl. Raya Tlogomas, No 246, Malang, Indonesia 65122
}

a rahmadhakim@umm.ac.id; b ${ }^{\text {muslikhati@umm.ac.id; cfitrian@umm.ac.id }}$

*Corresponding Author

DOI: https://doi.org/10.22219/jes.v5i2.14019

Check for updates

\begin{tabular}{|c|c|}
\hline & ABSTRACT \\
\hline $\begin{array}{l}\text { Keywords: } \\
\text { Islamic } \\
\text { Economics; } \\
\text { Islamic Values; } \\
\text { Islamic Ethics; } \\
\text { Economic } \\
\text { Development; } \\
\text { Coronavirus } \\
\text { Disease. }\end{array}$ & $\begin{array}{l}\text { This study aims to provide an in-depth analysis of Islamic economics } \\
\text { ethics on economic development in the time of coronavirus disease } \\
\text { (Covid-19). This research was qualitative, using documentation } \\
\text { techniques in data collection. The data analyzed using descriptive- } \\
\text { qualitative technique. The conclusion of this study found that Islamic } \\
\text { economic ethics in the economic development emphasizes on the role } \\
\text { of the invidual (society) and institutions (government) in an active } \\
\text { effort to manage the spread of coronavirus disease (Covid-19) by } \\
\text { avoid an excessive buying, consume the halal and thayyib food, } \\
\text { increase almsgiving activites and also the enforcement of fiscal and } \\
\text { monetary policy. }\end{array}$ \\
\hline
\end{tabular}

Article Info:

Submitted:

08/07/2020

Revised:

25/08/2020

Published:

30/08/2020

How to cite: Hakim, R., Muslikhati, M., \& Aprilianto, F. (2020). Islamic Economics Ethics Perspective on Economic Development in the Time of Coronavirus Disease (Covid-19). Falah: Jurnal Ekonomi Syariah, 5(2), 111-127. doi. https://doi.org/10.22219/jes.v5i2.14019 


\section{INTRODUCTION}

The spread of the coronavirus disease has not shown a decrease (Djalante, et. al., 2020). This disease was become the global issue around the world (Dehghanbanadaki, et. al., 2020). The corona virus pandemic has a negative impact on all aspects of people's lives, such as: health, social, political, education to the economy (Silalahi \& Ginting, 2020) and tourism sector (Karim, et. al., 2020).

However the economic sector is a sector that is significantly affected (Brodeur, et. al., 2020); (Iskandar, Possumah \& Aqbar, 2020). This condition of fear, uncertainty and greed, selfinterest and opportunistic (defective or unethical) behaviours of most individuals prevailing over societal collective interest amid the pandemic have been prevalently observed in the above instances, although a cooperative choice can eventually result in a better outcome for everyone (Ling \& Ho, 2020).

The negative impact on the economic sector can be seen in the decline in demand and supply of goods and services in the market (Fernandes, 2020; Nicola, et. al., 2020; Guerrieri, et. al., 2020; del Rio-Chanona, et. al., 2020). The decline in household consumption (demand side) encourages real GDP to decline in all scenarios of national economic growth. (Ding, et. al., 2017; Center for Macroeconomic Research at Xiamen University, \& Center for Macroeconomic Research at Xiamen University, 2020; Lahcen, et. al., 2020).

Even though during the Covid-19 Pandemic caused negative effect on wide areas of human life (Alabdullah, et. al., 2020). El Junusi (2020) found that advances in information technology played a role in the development of digital marketing. Ichsan, et. al., (2020) found that e-learning during the Covid-19 outbreak has gone well although some innovations.

Several research was conducted related to this topics. Islam, et. al., (2020) proposed the need for an alternative approaches to control the spread of disease. Some possible treatments for COVID-19 can be implemented such as vaccines and alternative medication such as natural compounds.

Altought managing the Covid-19 crisis was difficult for entrepreneurship educations, some alternative can be done is the use of augmented reality and artificial intelligence to simulate the real environment of entrepreneurship (Ratten, 2020). Because humanity and the formation of cognitive, social, value and human capital, leading to the preservation of elements of sustainable development and meeting the requirements of the times (Ali, 2020).

Fardin (2020) found that spirituality could aid people to have mental relaxation in times of crisis and dangerous diseases. This is in line with Koenig (2020) recommendation during the times of the COVID-19 pandemic th individuals should maintain their spiritual, mental, and physical resilience.

Ahmad \& Ahad (2020); Arifin \& Zaini (2020); Minhas (2020); Quadri (2020); Rifa'i, et. al., (2020) also found that by the study of the history, spread, and the treatment of the disease in islamic perspective, there are four steps need to be done as a the religious duties 
of Muslims which are isolation, quarantine, sanitation, and necessary immunization. Those methods are also recommended by the World Health Organization (WHO). In line Ashraf, et. al., (2020); Indriya (2020) discribe the good response to be done by every Muslim in this pandemic era such the act of quarantine by isolating the area affected by the virus, to be patient, to be kind and make efforts, to pray a lot (Ab Rahman, et. al., 2020; Bendebka, 2020; Rahman, 2020; Amanambu, 2020). Faris, et. al,. (2020) stated to impact of the dietary and lifestyle modifications on their impact on immunity.

Further Nuryana \& Fauzi (2020); Isiko (2020); Yezli \& Khan (2020) stated, that the educative movement by da'i (Islamic preacher) and Influencers (religious preachers) also become the alternative mathod to increase the community awareness on coronavirus disease -19 (Covid-19), altough the rule imposed by the government and Indonesia Ulema Council (MUI) in handling the pandemic outbreak did not include an investigation into Islam (Rajab, Nurdin \& Mubarak, 2020; Pabbajah, Said \& Faisal, 2020; Morales \& Morales, 2020).

On the other hand Darmawan, et, al., (2020); Subroto (2020) found there are changes pattern of worship activities carried out by Muslims in the era of pandemic COVID-19 which involves four variables are: the obligation of worship, the worship participation, the encouragement of social distancing, and the rationality of Muslims. Mahmuddin \& Syandri (2020) found that there are three groups who address the issue of destiny in different ways, which are jabariyah, qadariyyah and Ahlu Al Sunnah wal Jamaah group. However, the moderate and easiest one to support the maximization of government policy and the instructions of scholars in Indonesia was Ahlusunnah wal Jamaah, for the combination of belief in destiny with effort of man to maximize the achievement of the reliance process towards destiny.

In the discourse of ethical perspective of islamic economics, Dobson (1993) found that ethics function primarily as a constraint on behaviour. According to Reinhart (1983) found that roots (ușūl) of ethical understanding (fiqh) was a judgment (ḥukm) was reached in any particular case. Iqbal \& Mirakhor (2017); Choudhury \& Bhatti (2016) stated that ethics are embedded in the core principles of Islam. The various features of Islamic finance such as materiality, anti-fragility, stability, economic justice, and redistributive justice, these features address several ethical issues prevailing in global financial systems. Hakim (2016) stated that the aims of ethical principle of Islamic Economics was to to solve problems that occur particularly in the case of dichotomies in the fulfillment of material needs and non-material need.

Choudhury (1999) stated that a general systems view of interactions, integration and creative evolution among economic and social possibilities was shown to lead to the paradigm of Islamic political economy. On the other hand, Khan, M. A. (1994) found that the ethics in Islamic teaching based on welfare (maslahah) and morality of individuals in the society. A specific example showing the moral implications of debt and its relation with ethics. Uddin (2003) stated that Islam encourages the creation, acquisition and consumption of wealth, and the fulfilling of certain conditions in so doing. The ethical principles do play a major role in shaping the behavior of a Muslim in business. 
Choudhury (2018) found that tawhid (Oneness of Allah) was the ethical values in Islamis Economics, lay down methodological structure an the epistemology philosophy. Haneef \& Furqani (2009), Found that the concept of man as khalifah- 'abd is seen as having significant ethical implications on the development of economics and economic decision-making. Further Mahyudi \& Aziz (2017) argued that at the basis of microfoundation stage, the economic man imperative emerges out of this identification exercise. The most important implication was the replacement of homo Islamicus with the concept of 'universal man' which proffers several significant advantages. Hakim \& Syaputra (2013) found that amanah value as the one particular of Islamic business ethics in Islam.

Furqani (2015) proposed the key concepts of huquq, maslahah maximization and taqwa are the alternatives values to evaluate the negative values in mainstream economics such as self-interest, utility maximization and rationality. Mahyudi (2016); Furqani, Adnan \& Mulyany (2020) found that the ethical commitment of individuals (as envisaged in the micro-foundations of Islamic economics) would bring socio-macro implications in the practical realm.

Honarmand, Sorush, \& Haratian (2019), found the ethical school in Islamic economics attaches great importance to spirituality and considers the attention to materials to be legitimate to the extent that it does not hinder the spiritual growth and happiness of human beings. In line with this argument, Reardon (2019), stated the need for for pluralism as a compelling and necessary (but not sufficient) intellectual foundation for reform and concludes by logically pointing to the wisdom of Islamic economics. Further, Aydin (2018) found that there was the gap between those ideals and Muslim reality. For this discourse, therefore the need for internalizing moral axioms would serve as an ethical compass necessary to establish formal and informal institutions for efficient and ethical business organizations. Zarqa (2019) found that the assumption of selfishness of economic agents have to break from conventional economics. However, still to continue an engagement with conventional economics was necessary and mutually beneficial, provided due attention is given to the non-selfish sectors, and to behavioral and institutional reforms.

Abeng (1997) classified the essentials ethics in bussines are: the utmost importance of all sort of productive work and the distribution of wealth in society, the vocation of trade, and the fundamental principles of freedom and justice for business conduct; the prescription of certain manners such as leniency, service-motive, and consciousness of Allah; and mutual consultation. Furqani (2017) stated that Islamic Economics imply the moderation as the value of ethical principle in consumption. Hakim (2017) found that the concept of $t a^{\prime} d i b$ can be applied in the study of Islamic economic accordance with the key concept which stated in the al-Qur'an such as: al-fadlu, 'adl, maslahah, iqtishad, dan falah.

However there are limited study focused on the Islamic economics response to the impact of coronavirus disease (Covid-19) on the economic development and how its 
strategy to recover the economics of the nation, especially Indonesia. This study aims to provide an in-depth analysis of Islamic economics ethics on economic development in the time of coronavirus disease (Covid-19).

\section{RESEARCH METHOD}

This research was qualitative-descriptive to elaborate, describe, and explain thoroughly about the problem under the study, which is an in-depth analysis of Islamic economics ethics on economic development in the time of coronavirus disease (Covid19) (Sangalang, 2017; Sugiyono, 2004). Descriptive because this study aims to solve problems that exist in the present, on the other hand this research seeks to tell, analyze, and classify investigators (Surachmad, 1985).

The method used in the data collection process is the documentary method, which is to examine documents related to the object of research, including: text, photos, stories, pictures of facts and so on (Raco, 2003). The documentary method was used in this study (Creswel, 2014).

The data analysis technique used in this study was qualitative data analysis following three phases namely: data reduction, data display, and drawing a conclusion (Miles \& Huberman, 1992). Data reduction was done, after reading, studying, and reviewing all the sources, by summarizing the core of the materials. Subsequently abstraction was performed and finally the data interpretation conducted to find a result of the research.

\section{RESULT AND DISCUSSION}

Islamic economic ethics in economic development during the corona virus pandemic (Covid-19) can at least be differentiated into two levels of implementation, namely the implementation of Islamic economic ethics at the individual level and Islamic economic ethics at the institutional level, in this context the government.

At the individual level, there are four ethical implementations that can be carried out, namely: the need to consume halal and thayyib food, changing the patterns of consumption only to meet needs not desires, to avoid panic or excessive buying, to increase a giving behavior or social activities to help others.

Table 1. Islamic economic ethics in economic development during the corona virus pandemic (Covid-19)

\begin{tabular}{|c|c|c|}
\hline No. & $\begin{array}{c}\text { Level of } \\
\text { Implementation }\end{array}$ & The Praxies \\
\hline \multirow{4}{*}{1} & \multirow{4}{*}{ Individual level } & The need to consume halal and thayyib food \\
\hline & & $\begin{array}{l}\text { Turning the patterns of consumption only to meet } \\
\text { needs not desires }\end{array}$ \\
\hline & & To avoid panic or excessive buying \\
\hline & & To increase a giving behavior or social activities \\
\hline
\end{tabular}




\begin{tabular}{lll}
\hline \multirow{2}{*}{2} & \multirow{2}{*}{ Institutional level } & Fiscal policy enforcement \\
& Monetary policy enforcement \\
\hline
\end{tabular}

\section{The Need To Consume Only Halal and Thayyib Food}

In the Qur'an, the command to consume was mentioned 27 times. And several verses, it is stated that the types of food to be consumed are halal and thayyib (QS. AlBaqarah[2]: 168); (QS. Al-Ma'idah[5]: 88); (QS. Al-Anfal[8]: 69) dan (QS. An-Nahl[16]: 144). Based on the above verse, halal and thayyib are foods that should be consumed by a Muslim under ideal conditions.

Why are halal and thayyib mentioned together?, because lawful relating to the affairs of the hereafter, and thayyib related to worldly affairs. In addition, what is halal is not necessarily thayyib to eat, and thayyib is not necessarily halal to eat.

Some foods are not in the category of halal and thayyib as stated in the Qur'an (QS. AlMaidah[5]: 3) if it include under the following three criteria: first, food that has become carcass (animals that die not because of being slaughtered). Second, pork and dogs. Third, animals that are slaughtered are not intended for worship of Allah.

Additional criteria are contained in the words of the Prophet Muhammad in his words, such as (1) the prohibition of eating tame donkey meat (luhum humuri al-ahliyyah) (HR. Muttafaqun 'Alaih), (2) the fanged and savage animal (dzi nabin min as-sabuhi) (HR. Muttafaqun 'Alaih), (3) animal (bird) with claws (mikhlabin min at-thairi) (HR. Muslim), (4) prohibition of eating meat and milk from halal animals but most of them eat unclean food (al-jallalah) (HR. Abu Dawud, at-Tirmidzi \& Ibnu Majah). (5) prohibition of eating meat of animals that disturb humans, including: rats, scorpions, eagles and crows (HR. Bukhari dan Muslim). (6) a disgusting animal.

Based on the disaster, in the form of a coronavirus disease (Covid-19) that occurred in Wuhan City, Hubei Province, China, giving us a valuable lesson, that the prohibition of consuming food that is outside the halal and thayyib categories, such as animals that are fanged, unclean, have claws, eaters (meat) has an impact that is quite dangerous not only for themselves (those who consume food), but also able to be dangerous for humans around and even the entire population of the earth. As we know, the coronavirus has spread to all around the world more than 50 Countries and 4 Continents (Asia, America, Europe and Africa). Thus, the command to eat halal food and thayyib is actually an order from God which is at the same time for humanity by providing the safety of mankind in the world and saving us in the hereafter (Azmi, 2019; Rahman, Hassan \& Mohammad, 2020; Harahap, Azmi \& Arif, 2020).

\section{Turning the patterns of consumption}

The purpose of consumption is to maximize the value of economic activities with the resources owned (income) (Sukirno, 2009). However, it would be wiser if as consumers, we can adjust consumption patterns so that we do not panic buying which 
actually causes inflation (Donthu \& Gustafsson, 2020). As taught in Islam, shopping according to needs and not exceeding the limit (wasteful) is the key to controlling the inflation rate (QS. al-A'raf[7]: 31).

In this case, Rasulullah saw in a saying that gives a little easy picture, that in proper consumption the stomach should be filled with one third (1/3) of food, one third $(1 / 3)$ of drink and another one third (1/3) for the air used for breathing (HR. Muslim). In line with that as stated by Khalid (2006), a friend of the Messenger of Allah Salman alFarisi said that he always divided his income into three parts. The first part was for daily needs, partly for business capital, and partly for alms. This information told us that Islamic consumption is not to spend excessively so that the stake is bigger than a pole.

In order to make it easier to avoid consumptive behavior, Al-Ghazali has divided the priority of meeting needs into three parts (Syaputra, 2017): primary needs or basic needs, secondary needs and luxurious need.

In the context of pandemic corona virus (Covid-19) era, it is can be explain as foolows: first, basic needs or primary (dharuriyyat) needs such as clothing, food and shelter. Second, secondary needs (hajiyat), namely complementary or supporting needs such as hand sanitizers or masks. Third, luxurious need (tahsiniyyat), namely the need for perfecting individual conditions such as the internet and smartphones.

\section{To avoid a panic or excessive buying}

Along with the increasing development of the coronavirus (Covid-19) pandemic, Indonesia must also prepare for other viruses that attack macroeconomic stability, namely excessive public consumption behavior that causes inflation. Excessive consumption behavior arises as a result of excessive anticipation of food shortages when they are urged to stay indoors (work from home) and reduce outdoor activities during the massive spread of this virus pandemic (Mollenkopf, et. al., 2020). There needs to be participation and collaboration from economic entities to realize regulations so that they are able to control various economic problems, especially when conditions are unpredictable (unpredictable) (Bispo Júnior \& Morais, 2020).

Excess consumption can have an impact on the economy, such as price increases that lead to inflation (Pham, et. al., 2019). Inflation itself by definition is the tendency of prices in general to increase continuously (Dornbush, Fischer, \& Startz, 2014). The panic caused by the Covid-19 pandemic led the Indonesian people to carry out actions to buy basic necessities which resulted in the scarcity of several items such as foodstuffs, medicines, masks and hand sanitizers in several areas (Salisu \& Akanni, 2020; Yunus \& Rezki, 2020).

Inflation is not only the duty of policy makers, but also economic entities that involve themselves in economic activities in the form of production, distribution and consumption. Given the effects of the pandemic and inflation, it is very disruptive to economic stability in developing countries, even resulting in economic recession (Mankiw, 2003; Barbier \& Burgess, 2020; Erokhin \& Gao, 2020). So there needs to be control from economic actors consisting of government, public, and household in 
regulating the availability of foodstuffs and consumption patterns, at least in the form of appeals (moral persuasion) (Greenacre \& Akbar, 2019; Mohamed, et. al., 2020).

\section{To increase a giving behavior or social activities}

It seems that we need to emulate the altruism and philanthropic spirit above at the time of the current pandemic outbreak. Where the vision of zakat, infaq and alms is for the welfare of the ummah, by taking some of the wealth of the rich to give to the poor. So that wealth does not only rotate in certain groups.

With the willingness and care of the rich to the poor, will result in the emergence of harmony between the two. Because humans are social creatures (al-Insanu madaniyyun bi at-thab 'i) and a believer is like a solid building, which mutually emphasize one another (yasyuddu ba'duhum ba'dhan) (HR. Bukhari \& Muslim).

According to Khaldun, the glory and existence of a group or nation is determined by the level of social solidarity ('ashabiyyah) between elements of the group or nation, between ulama, state officials, businessmen or ordinary people (Gierer, 2001; Karatas, 2006; Ardic, 2012). Moreover, Scharmer \& Kaufer (2013) states that the change from ego-system to eco-system is important to do now for the realization of the welfare of the global community and the earth's ecosystem with care for others.

With its social capital, Indonesia is the most generous country in the world in 2018 (World Giving Index 2018) based on the release of the Charities Aid Foundation (CAF) and the increasing trend in the receipt of national zakat funds in Indonesia (collected IDR. 5,12 trillion in 2016; IDR.6 trillion in 2017; IDR.8,1 trillion in 2018; IDR. 10,07 trillion in 2019). Alms giving in is the right natural solution during the pandemic situation, especially in the form of zakah (Hambari, Arif \& Zaim, 2020).

On the other hand, the publication Fatwa of the Indonesia Ulema Council (MUI) No. 23 year 2020 concerning the Use of Zakat, Infaq and Shadaqah (ZIS) assets for the prevention of Covid-19 and its impact confirms that almsgiving (zakah, infaq and shadaqah) is very meaningful for the economic support of the community.

\section{Institutional Economic Policy Alternatives for Social Safety}

The coronavirus (Covid-19) pandemic has a negative impact on all aspects of people's lives, such as: health, social, political, education to the economy (Silalahi \& Ginting, 2020). However the economic sector is a sector that is significantly affected (Brodeur, et. al., 2020); (Iskandar, Possumah \& Aqbar, 2020).

The negative impact on the economic sector can be seen in the decline in demand and supply of goods and services in the market. Furthermore, the decline in household consumption (demand side) will encourage real GDP to decline in all scenarios for national economic growth (Firdaus, et. al., 2020). The producer sector will respond to the decline in household consumption by reducing production capacity (supply side). The reduced production capacity will certainly reduce the income from the producer side. This 
Vol. 5 No. 2 (2020)

ISSN (print): 2502-3918 | ISSN (online): 2502-7824

condition causes producers or industries to bear the burden of production factors, such as labor, electricity, water, telephone, rent, taxes, debt and loan interest (Muhyiddin, 2020).

Based on World Bank data releases, Indonesia's economic growth prediction is only around $2.1 \%$ to $-3.5 \%$ in 2020 (Yamali \& Putri, 2020). In line with this, the Asian Development Bank (ADB) predicts Indonesia's economic growth of 2.5\%. Bank Indonesia (BI) also agreed with this with a correction in economic growth to $2 \%$ from the previous economic growth target of 5\%. In a more extreme way, the Minister of Finance Sri Mulyani Indrawati allows it to be minus four percent $(-0.4 \%)$ this year.

In this regard, in general, macroeconomic policy can be pursued through two policy proxies, namely fiscal policy and monetary policy.

Fiscal policy alternatives that can be carried out during this pandemic include: first, the application of the Government's budget reallocation to overcome the economic crisis due to the impact of the coronavirus pandemic (Kurniawansyah, et. al., 2020). Second, reducing the Government's Expenditure Budget by cutting salaries at the level of ministerial officials or agencies at the ministry level and Regional Head Office until the end of the year in order to reduce the burden on the State Budget.

Third, to provide direct cash assistance (Bantuan Langsung Tunai) programs for people affected by the pandemic, especially the middle to lower class. In this category are day laborers, hawkers or street vendors, farmers, fishermen and MSMEs. Fourth, the government have to ensure the availability of foodstuffs stock for the community. Therefore, monopolistic practices, hoarding of goods are things that need to be minimized. This is because the hoarding of staples results in scarcity of goods in the community which will lead to inflation.

Fifth, to decrease the price of fuel oil (Bahan Bakar Minyak). This option can be carried out by the government considering that world oil prices are currently falling. This policy will reduce the burden on public spending. Sixth, relaxation of the tax burden of Pajak Penghasilan (PPh) 21, PPh 22, PPh 25 and exemption from Pajak Pertambahan Nilai (PPN) until the end of 2020 (Hastuti, 2020). Seventh, to avoid loans from foreign parties (World Bank or International Monetary Fund). This can be done if the central government carries out a budget reallocation policy, so that there will be enough funds available to deal with the impact of the corona virus pandemic.

Table 2. The Institutional Economic Policy Alternatives for Social Safety

\begin{tabular}{|c|c|c|}
\hline No. & Policy & Proxy of Policy \\
\hline \multirow{7}{*}{1} & \multirow{7}{*}{ Fiscal Policy } & a) the Government's budget reallocation \\
\hline & & b) reducing the Government's Expenditure Budget \\
\hline & & c) to Provide direct cash assistance programs \\
\hline & & $\begin{array}{l}\text { d) to ensure the availability of foodstuffs stock for the } \\
\text { community }\end{array}$ \\
\hline & & e) to decrease the price of fuel oil \\
\hline & & f) the relaxation of the tax burden \\
\hline & & g) to avoid loans from foreign parties \\
\hline
\end{tabular}


ISSN (print): 2502-3918 | ISSN (online): 2502-7824

\begin{tabular}{lll}
\hline 2 & Monetary Policy & $\begin{array}{l}\text { to reduce the 7-Day Repo Rate or Bank Indonesia Interest } \\
\text { Rate }\end{array}$ \\
\hline & to provide leniency in credit installment payments \\
\hline $\begin{array}{l}\text { the limitation on consumptive lending to financial } \\
\text { institutions }\end{array}$ \\
\hline $\begin{array}{l}\text { to increase the statutory reserve requirement for financial } \\
\text { institutions at Bank Indonesia }\end{array}$ \\
\hline \multirow{2}{*}{ Other alternative Policy } & $\begin{array}{l}\text { Areal lock-down, regional quarantine, large-scale social } \\
\text { restrictions }\end{array}$ \\
\hline
\end{tabular}

Meanwhile, on the monetary policy side several policy alternatives are needed, such as: first, to reduce the 7-Day Repo Rate or Bank Indonesia Interest Rate (Noval \& Nadia, 2020). Where the current benchmark interest rate set by Bank Indonesia is $4.5 \%$, the reduction in the benchmark interest rate can be reduced back to the level of 2.5\% $3 \%$. This can ease the burden on households or producers who have loan facilities on banks. Second, to provide leniency in credit installment payments. Allowance for credit is given to the tourism sector, MSMEs, and online transportation drivers until the end of the year. The provision of leniency in credit for the three sectors is because they are considered quite seriously affected by COVID-19 (Ubaidillah \& Aji, 2020).

Third, the limitation on consumptive lending to financial institutions. Fourth, to increase the statutory reserve requirement (Giro Wajib Minimum) for financial institutions at Bank Indonesia (Sibarani, 2016). An increase in statutory reserves will have an impact on the amount of credit or financing that is getting smaller. This condition led to relatively controlled money creation by financial institutions (banks). In addition, the increase in reserve requirements will also increase banking liquidity.

Other alternative policy can be enforced to manage the spread of the coronavirus (Covid-19) pandemic as follow: lock-down, regional quarantine, large-scale social restrictions or other alternative policy. This policy is important to do in order to avoid the impact of an even more extreme economic downturn. Even though it is clear that this pandemic will lead to a world economic recession, especially for Indonesia.

However, minimizing the possibility of harm must be done in order to avoid the possibility of a worse impact on the economy (Rusiadi et. al., 2020). Indonesia must give up the decline in its economic growth in order to save public health. This policy is important in order to save Indonesia's economy in the future. This is because economic growth will exist if the people are healthy.

\section{CONCLUSION}

Based on the discussion, it was found that Islamic economic ethics in the economic development emphasizes on the role of the invidual (society) and institutions (government) in an active effort to manage the spread of coronavirus disease (Covid-19) by avoid an excessive buying, consume the halal and thayyib food, increase the alms giving activites and also the enforcement of fiscal and monetary policy. 
Vol. 5 No. 2 (2020)

ISSN (print): 2502-3918 | ISSN (online): 2502-7824

However, future research may add further research on the impact of Islamic values on the economic resilience of society, especially in Indonesia for more ideal model of the research.

\section{REFERENCES}

Ab Rahman, Z., Kashim, M. I. A. M., Mohd Noor, A. Y., Che Zarrina Saari, A. Z. H., Abdul Rahim Ridzuan, A. R. R., \& Hanizah Mohd Yusoff, W. H. K. (2020). Critical review of positive behavior and resilience in Islamic perspective during the COVID 19 pandemic. Journal of Critical Reviews, 7(5), 1117-1125. Retrieved from https://www.researchgate.net/profile/Zaizul_Rahman/publication/343063856_CRITICAL_ REVIEW_OF_POSITIVE_BEHAVIOR_AND_RESILIENCE_IN_ISLAMIC_PERSPEC TIVE DURING THE COVID 19 PANDEMIC $=$

Abeng, T. (1997). Business ethics in Islamic context: Perspectives of a Muslim business leader. Business Ethics Quarterly, 47-54. https://doi.org/10.2307/3857312

Ahmad, Z., \& Ahad, A. (2020). COVID-19: A Study of Islamic and Scientific Perspectives. Theology and Science, 1-10. https://doi.org/10.1080/14746700.2020.1825192

Ahmed, H. (2011, December). Defining ethics in Islamic finance: Looking beyond legality. In Eighth International Conference on Islamic Economics \& Finance: Sustainable Growth And Inclusive Economic Development from an Islamic Perspective 2011 (pp. 19-21). Retrieved from http://www.iefpedia.com/english/wp-content/uploads/2011/12/HabibAhmed.pdf

Alabdullah, T. T. Y., Ahmed, E. R., \& Nor, M. I. (2020). The World Declining Economy And Coronavirus Pandemic: Systems Should Be Continued. Russian Journal of Agricultural and Socio-Economic Sciences, 102, 89-96. Retrieved from https://www.researchgate.net/profile/Tariq_Alabdullah/post/We published new paper ab out_COVID-

Ali, A. (2020). The Reality Of Development And Management Of Human Resources In Light Of Transformations After Covid 19 Economic: Social And Islam's Perspective. Journal of Global Business and Social Entrepreneurship (GBSE), 6(19). Retrieved from http://gbse.com.my/V6\%20NO.19\%20(SEPTEMBER\%202020)/Paper-251-.pdf

Amanambu, U. E. (2020). Almajiri Islamic practices and the COVID-19 pandemic in Nigeria: matters arising. Journal of Applied Philosophy, 18(3), 88-106. doi. $\underline{10.13140 / R G \cdot 2 \cdot 2 \cdot 15971.99366}$

Ardic, N. (2012). Genealogy or Asabiyya? Ibn Khaldun between Arab Nationalism and the Ottoman Caliphate. Journal of Near Eastern Studies, 71(2), 315-324. https://doi.org/10.1086/666697

Arifin, S., \& Zaini, A. (2020). Decision of Implementing Uzlah and Gerbat Techniques in Islamic Boarding School as Preparedness Response for Covid-19 Pandemic. Unnes Journal of Public Health, 9(2), 126-134. https://doi.org/10.15294/ujph.v9i2.38107

Ashraf, H., Faraz, A., Raihan, M., \& Kalra, S. (2020). Fighting pandemics: Inspiration from Islam. JPMA. The Journal of the Pakistan Medical Association, 70(5), 152-156. Retrieved from https://www.jpma.org.pk/PdfDownloadsupplements/486

Asutay, M. (2007). A political economy approach to Islamic economics: Systemic understanding for an alternative economic system. Kyoto bulletin of Islamic area studies, 1(2), 3-18. Retrieved from https://kias.asafas.kyotou.ac.jp/1st_period/contents/pdf/kb1_2/04asutay.pdf

Aydin, N. (2018). Moral economic axioms, preference formation and welfare in Islamic economics and business. Asian Journal of Business Ethics, 7(1), 21-36. https://doi.org/10.1007/s13520-017-0077-7

Azmi, M. U. (2019). The Consumption Behavior of Moslem: A Maqashid Shariah Approach toward Foundational Consumptioan Theory in Islam Economics. AL-FALAH: Journal of 
Islamic Economics, 4(2), 197-210. 10.29240/alfalah.v4i2.933

Barbier, E. B., \& Burgess, J. C. (2020). Sustainability and development after COVID-19. World Development, 135, 105082. https://doi.org/10.1016/j.worlddev.2020.105082

Bendebka, R. (2020). Preventive Medicine and Maqasid Al-Shari'ah: The case of COVID-19. Revelation and Science, 10(1). Retrieved from https://journals.iium.edu.my/revival/index.php/revival/article/view/259

Bispo Júnior, J. P., \& Morais, M. B. (2020). Community participation in the fight against COVID19: between utilitarianism and social justice. Cadernos de saude publica, 36(8), e00151620, 1-9. https://doi.org/10.1590/0102-311X00151620

Brodeur, A., Gray, D. M., Islam, A., \& Bhuiyan, S. (2020). A Literature Review of the Economics of COVID-19. IZA Discussion Paper No. 13411, Available at SSRN: https://ssrn.com/abstract=3636640. $\quad$ Retrieved from https://papers.ssrn.com/sol3/papers.cfm?abstract_id=3636640

Center for Macroeconomic Research at Xiamen University, \& Center for Macroeconomic Research at Xiamen University. (2020). The Policy Effects in Responding to COVID-19. China's Macroeconomic Outlook: Quarterly Forecast and Analysis Report, March 2020, 39-48. https://doi.org/10.1016/j.apenergy.2017.06.003

Choudhury, M. A. (1999). The structure of Islamic economics: a comparative perspective on markets, ethics and economics. Consumption, Markets and Culture, 3(1), 61-97. https://doi.org/10.1080/10253866.1999.9670330

Choudhury, M. A. (2018). Tawhidi Islamic economics in reference to the methodology arising from the Qur'àn and the Sunnah. ISRA International Journal of Islamic Finance, 10(2), 263276. https://doi.org/10.1108/IJIF-02-2018-0025

Choudhury, M. A., \& Bhatti, I. (2016). Heterodox Islamic Economics: The emergence of an ethico-economic theory. Routledge. Retrieved from https://books.google.co.id/books?hl=en\&lr=\&id=0mrADAAAQBAJ\&oi=fnd\&pg=PP1\&d q=Islamic+Economics+Ethics\&ots=d11TXWhbLM\&sig=DtZRwEkvdZ1I-

qKLBpqMjTb0xGE\&redir_esc=y\#v=onepage\&q=Islamic\%20Economics\%20Ethics\&f=fa $\underline{\text { lse }}$

Darmawan, D., Miharja, D., Waluyajati, R. S. R., \& Isnaeniah, E. (2020). Sikap Keberagamaan Masyarakat Menghadapi Wabah COVID-19. Religious: Jurnal Studi Agama-Agama Dan Lintas Budaya, 4(2), 115-124. https://doi.org/10.15575/rjsalb.v4i2.8596

Dehghanbanadaki, H., Seif, F., Vahidi, Y., Razi, F., Hashemi, E., Khoshmirsafa, M., \& Aazami, H. (2020). Bibliometric analysis of global scientific research on Coronavirus (COVID-19). Medical Journal of The Islamic Republic of Iran (MJIRI), 34(1), 354-362. Retrieved from http://mjiri.iums.ac.ir/browse.php?a id=6629\&slc lang=en\&sid=1\&printcase $=1 \&$ hbnr $=1$ $\& \mathrm{hmb}=1$

del Rio-Chanona, R. M., Mealy, P., Pichler, A., Lafond, F., \& Farmer, D. (2020). Supply and demand shocks in the COVID-19 pandemic: An industry and occupation perspective. arXiv preprint arXiv:2004.06759. https://doi.org/10.1093/oxrep/graa033

Ding, Q., Cai, W., Wang, C., \& Sanwal, M. (2017). The relationships between household consumption activities and energy consumption in china - an input-output analysis from the lifestyle perspective. Applied energy, 207, 520-532. https://doi.org/10.1016/j.apenergy.2017.06.003

Djalante, R., Lassa, J., Setiamarga, D., Mahfud, C., Sudjatma, A., Indrawan, M., \& Gunawan, L. A. (2020). Review and analysis of current responses to COVID-19 in Indonesia: Period of January to March 2020. Progress in Disaster Science, 100091. https://doi.org/10.1016/j.pdisas.2020.100091

Dobson, J. (1993). The role of ethics in finance. Financial Analysts Journal, 49(6), 57-61. https://doi.org/10.2469/faj.v49.n6.57

Donthu, N., \& Gustafsson, A. (2020). Effects of COVID-19 on business and research. Journal of 
Vol. 5 No. 2 (2020)

ISSN (print): 2502-3918 | ISSN (online): 2502-7824

business research, 117, 284-289. 10.1016/j.jbusres.2020.06.008

Dornbush, R., Fischer, S., \& Startz, R. (2014). Makroekonomi (ed. Y. Wibisono \& RI Mirazudin). Jakarta: PT Media Global Edukasi.

El Junusi, R. (2020). Digital Marketing During the Pandemic Period; A Study of Islamic Perspective. Journal of Digital Marketing and Halal Industry, 2(1), 15-28. 10.21580/jdmhi.2020.2.1.5717

Erokhin, V., \& Gao, T. (2020). Impacts of COVID-19 on trade and economic aspects of food security: Evidence from 45 developing countries. International journal of environmental research and public health, 17(16), 57-75. https://doi.org/10.3390/ijerph17165775

Fahlevi, M. (2019, August). The Influence of Exchange Rate, Interest Rate and Inflation on Stock Price of LQ45 Index in Indonesia. In First International Conference on Administration Science (ICAS 2019). Atlantis Press, 157-163. https://doi.org/10.2991/icas-19.2019.34

Fardin, M. A. (2020). COVID-19 epidemic and spirituality: A Review of the benefits of religion in times of crisis. Jundishapur Journal of Chronic Disease Care, 9(2). e104260. doi: $10.5812 /$ jjcdc. 104260.

Faris, M. E. A., Salem, M., Jahrami, H., Madkour, M., \& BaHammam, A. (2020). Ramadan intermittent fasting and immunity: An important topic in the era of COVID-19. Annals of Thoracic Medicine, 15(3), 125-133. Retrieved from https://web.a.ebscohost.com/abstract?direct=true\&profile=ehost\&scope=site \&authtype $=\mathrm{cr}$ awler\&jrnl=18171737\&AN=144220571\&h=fSgETMZVulbHcPre5G6cMhUeMgKZo02Y 7rs8\%2fT805or8jVcexJ2CxMTNHA5wya4k561Z5IfMoTMA90Y7

Fernandes, N. (2020). Economic effects of coronavirus outbreak (COVID-19) on the world economy. IESE Business School Working Paper No. WP-1240-E, Available at SSRN: https://ssrn.com/abstract=3557504 or http://dx.doi.org/10.2139/ssrn.3557504

Firdaus, A. H., Listiyanto, E., Talattov, A. P., \& Taufikurahman, M. R. Kajian Tengah Tahun INDEF 2020: Menata Arsitektur Ekonomi Pasca Pandemi. INDEF.

Furqani, H. (2015). Individual and society in an Islamic ethical framework: Exploring key terminologies and the micro-foundations of Islamic economics. Humanomics, 31(1), 74-87. https://doi.org/10.1108/H-04-2014-0037

Furqani, H. (2017). Consumption and morality: Principles and behavioral framework in Islamic economics. Journal of King Abdulaziz University: Islamic Economics, 30, 89-102. https://doi.org/ 10.4197 / Islec. 30-SI.6

Furqani, H., Adnan, G., \& Mulyany, R. (2020). Ethics in Islamic economics: microfoundations for an ethical endogeneity. International Journal of Ethics and Systems, 36(3), 449-463. https://doi.org/10.1108/IJOES-03-2020-0032

Gierer, A. (2001). Ibn Khaldun on solidarity ("Asabiyah")-modern science on cooperativeness and empathy: a Comparison. Philosophia Naturalis, 38(1), 91-104. Retrieved from https://philarchive.org/rec/GIEIKO

Greenacre, L., \& Akbar, S. (2019). The impact of payment method on shopping behaviour among low income consumers. Journal of Retailing and Consumer Services, 47, 87-93. https://doi.org/10.1016/j.jretconser.2018.11.004

Guerrieri, V., Lorenzoni, G., Straub, L., \& Werning, I. (2020). Macroeconomic Implications of COVID-19: Can Negative Supply Shocks Cause Demand Shortages?. National Bureau of Economic Research. 1-36. https://doi.org/10.3386/w26918

Hakim, R., \& Syaputra, E. (2013). Business as Al-amanah and the responsibilities of Islamic business managers. La_Riba, 6(2), 199-210. Retrieved from https://www.researchgate.net/profile/Rahmad Hakim/publication/292341091 BUSINESS AS_AL-

AMANAH AND THE RESPONSIBILITIES OF ISLAMIC BUSINESS MANAGER S/links/5c18a0f0a6fdcc494ffc8a54/BUSINESS-AS-AL-AMANAH-AND-THERESPONSIBILITIES-OF-ISLAMIC-BUSINESS-MANAGERS.pdf

Hakim, R. (2016). Islamic economists in the early 21 st century view's on business ethics. Falah: 
Jurnal Ekonomi Syariah, 1(1), 1-13. https://doi.org/10.22219/jes.v1i1.2691

Hakim, R. (2017). Penerapan Konsep Ta'dib dalam Pembelajaran Ekonomi Syariah. Falah: Jurnal Ekonomi Syariah, 2(2), 211-225. https://doi.org/10.22219/jes.v2i2.5107

Hambari, H., Arif, A. A., \& Zaim, M. A. (2020, October). The Role of Zakat Institution in Facing Covid-19. In International Conference of Zakat (pp. 119-126). https://doi.org/10.37706/iconz.2020.225

Haneef, M. A., \& Furqani, H. (2009). Developing the ethical foundations of Islamic economics: Benefitting from Toshihiko Izutsu. Intellectual Discourse, 17(2), 173-199. Retrieved from https://journals.iium.edu.my/intdiscourse/index.php/id/article/view/77

Hastuti, R. (2020). Stimulus Pajak dan Geliat WP: Melawan Belenggu Corona. Retreived from http://repository.unika.ac.id/22123/

Honarmand, S. M., Sorush, J., \& Haratian, A. (2019). Ethical School in Islamic Economics and Conventional Economics. Research Quarterly in Islamic Ethics, 12(46), 57-70. Retrieved from http://akhlagh.maaref.ac.ir/article-1-1308-en.html

Harahap, S. A. R., Azmi, M. U., \& Arif, A. (2020). Muslim Consumer Behavior In The Sharia Maqosid Perspective. Ijtihad: Jurnal Hukum dan Ekonomi Islam, 14(1), 119-135. http://dx.doi.org/10.21111/ijtihad.v14i1.4508

Ichsan, I. Z., Rahmayanti, H., Purwanto, A., \& Sigit, D. V. (2020). COVID-19 Outbreak on Environment: Profile of Islamic University Students in HOTS-AEP-COVID-19 and PEBCOVID-19. Online Submission, 5(1), 167-178. https://doi.org/10.24042/tadris.v5i1.6283

Indriya, I. (2020). Konsep Tafakkur Dalam Alquran Dalam Menyikapi Coronavirus Covid-19. SALAM: Jurnal Sosial dan Budaya Syar-i, 7(3), 211-216. https://doi.org/10.15408/sjsbs.v7i3.15050

Iqbal, Z., \& Mirakhor, A. (2017). Ethical dimensions of Islamic economics and finance. In Ethical Dimensions of Islamic Finance (pp. 103-134). Palgrave Macmillan, Cham. Retrieved from https://link.springer.com/chapter/10.1007/978-3-319-66390-6_5

Isiko, A. P. (2020). Religious construction of disease: An exploratory appraisal of religious responses to the COVID-19 pandemic in Uganda. Journal of African Studies and Development, 12(3), 77-96. https://doi.org/10.5897/JASD2020.0573

Iskandar, A., Possumah, B. T., \& Aqbar, K. (2020). Peran Ekonomi dan Keuangan Sosial Islam saat Pandemi Covid-19. Salam J. Sos. dan Budaya Syar'i, 7(7), 625-638. https://10.15408/sjsbs.v7i7.15544

Islam, M. T., Nasiruddin, M., Khan, I. N., Mishra, S. K., Kudrat-E-Zahan, M., Riaz, T. A., ... \& Cho, W. C. (2020). A perspective on emerging therapeutic interventions for COVID-19. Frontiers in public health, 8. 281. https//doi.10.3389/fpubh.2020.00281

Karim, W., Haque, A., Anis, Z., \& Ulfy, M. A. (2020). The movement control order (mco) for covid-19 crisis and its impact on tourism and hospitality sector in malaysia. International Tourism and Hopitality Yournal, 3(2), 1-7. Retrieved from https://rpajournals.com/wpcontent/uploads/2020/04/ITHJ-2020-02-09.pdf

Khalid, K. M. (2006). Karakteristik perihidup enam puluh sahabat Rasulullah. Bandung. Penerbit Diponegoro.

Karatas, S. C. (2006). Economic theory of Ibn Khaldun and rise and fall of nations. Foundation for Science Technology and Civilisation. Retrieved from https://d1wqtxts1xzle7.cloudfront.net/32526647/The_Economic_Theory_of_Ibn_Khaldun. pdf?1386738715=\&r

Koenig, H. G. (2020). Maintaining health and well-being by putting faith into action during the COVID-19 pandemic. Journal of Religion and Health, 59(1), 2205-2214. Retrieved from https://link.springer.com/content/pdf/10.1007/s10943-020-01035-2.pdf

Kurniawansyah, H., Amrullah, A., Salahuddin, M., Muslim, M., \& Nurhidayati, S. (2020). Konsep Kebijakan Strategis Dalam Menangani Eksternalitas Ekonomi dari Covid-19 Pada Masyarakat Rentan di Indonesia. Indonesian Journal of Social Sciences and Humanities, 
Vol. 5 No. 2 (2020)

ISSN (print): 2502-3918 | ISSN (online): 2502-7824

l(2), 130-139. Retrieved from https://journal.publication-

center.com/index.php/ijssh/article/view/117

Lahcen, B., Brusselaers, J., Vrancken, K., Dams, Y., Paes, C. D. S., Eyckmans, J., \& Rousseau, S. (2020). Green recovery policies for the COVID-19 crisis: modelling the Impact on the economy and greenhouse gas emissions. Environmental and Resource Economics, 76(4), 731-750. Retrieved from https://link.springer.com/article/10.1007/s10640-020-00454-9

Ling, G. H. T., \& Ho, C. M. C. (2020). Effects of the coronavirus (COVID-19) pandemic on social behaviours: From a social dilemma perspective. Technium Social Sciences Journal, 7(1), 312-320. Retrieved from https://www.researchgate.net/publication/341166021_Effects_of_the_Coronavirus_COVI D-19 Pandemic on Social Behaviours From a Social Dilemma Perspective

Mahmuddin, R., \& Syandri, S. (2020). Qadariyah, Jabariyah dan Ahlus Sunnah (Studi Komparatif Merespon Kebijakan Pemerintah dan Ulama Mencegah Merebaknya Covid-19). BUSTANUL FUQAHA: Jurnal Bidang Hukum Islam, I(2), 209-222. https://doi.org/10.36701/bustanul.v1i2.147

Mahyudi, M. (2016). Rethinking the concept of economic man and its relevance to the future of Islamic economics. Intellectual Discourse, 24(1), 111-132. Retrieved from https://journals.iium.edu.my/intdiscourse/index.php/id/article/view/713

Mahyudi, M., \& Aziz, E. A. (2017). Rethinking the structure of Islamic economics science: The universal man imperative. International Journal of Economics, Management and Accounting, 25(2), 227-251. Retrieved from https://journals.iium.edu.my/enmjournal/index.php/enmj/article/view/487

Mankiw, N. G. (2003). Teori Makroekonomi edisi kelima. Jakarta: Erlangga.

Mannan, M. A. (1980). Islamic Economics. Idarah-i Adabiyat-i Delli.

Minhas, Q. (2020). Analysis of Circumspections of COVID19 in the Light of Islam (July 8, 2020), 1-7. http://dx.doi.org/10.2139/ssrn.3645952

Mohamed, K., Rodríguez-Román, E., Rahmani, F., Zhang, H., Ivanovska, M., Makka, S. A., \& Rahmah, L. (2020). Borderless collaboration is needed for COVID-19-A disease that knows no borders. Infection Control \& Hospital Epidemiology, 1-2. Retrieved from https://www.cambridge.org/core/journals/infection-control-and-hospitalepidemiology/article/borderless-collaboration-is-needed-for-covid19a-disease-that-knowsno-borders/CDC82720199AC7BE4654F123DB79508E

Mollenkopf, D. A., Ozanne, L. K., \& Stolze, H. J. (2020). A transformative supply chain response to COVID-19. Journal of Service Management. https://doi.org/10.1108/JOSM-05-20200143

Morales, Y. R., \& Morales, S. R. (2020). Responses to Fatwas of Islamic Religious Leaders and Institutions during the Coronavirus Disease (COVID-19) in the Philippines: Looking at How Guidance Was Provided to Muslim Communities in the Philippines. http://dx.doi.org/10.2139/ssrn.3678425

Muhyiddin, M. (2020). Covid-19, New Normal, dan Perencanaan Pembangunan di Indonesia. The Indonesian Journal of Development Planning, 4(2), 240-252. https://doi.org/10.36574/jpp.v4i2.118

Nicola, M., Alsafi, Z., Sohrabi, C., Kerwan, A., Al-Jabir, A., Iosifidis, C. \& Agha, R. (2020). The socio-economic implications of the coronavirus and COVID-19 pandemic: a review. International Journal of Surgery, 78, 185-193. https://doi.org/10.1016/j.ijsu.2020.04.018

Noval, N., \& Nadia, N. (2020). Pengaruh Inflasi Terhadap Jakarta Islamic Index (JII) Dengan BI 7 Day Repo Rate Sebagai Variabel Moderating Dan Nilai Tukar (IDR/USD) Sebagai Variabel Intervening. Jurnal Ilmu Perbankan dan Keuangan Syariah, 2(1), 1-23. https://doi.org/10.24239/jipsya.v2i1.20.1-23

Nuryana, Z., \& Fauzi, N. A. F. (2020). The Fiqh of disaster: The mitigation of covid-19 in the perspective of Islamic education-neuroscience. International Journal of Disaster Risk Reduction, 51, 101848. https://doi.org/10.1016/j.ijdrr.2020.101848 
Pabbajah, M., Said, N. M., \& Faisal, M. (2020). Deauthorization of the Religious Leader Role in Countering Covid-19: Perceptions and Responses of Muslim Societies on the Ulama's Policies in Indonesia. International Journal, 9(1), 263-273. Retrieved from https://www.researchgate.net/profile/Mustaqim_Pabbajah/publication/343382057_Deauth orization of the Religious Leader Role in Countering Covid-

Pham, T. H., Nguyen, T. N., Phan, T. T. H., \& Nguyen, N. T. (2019). Evaluating the purchase behaviour of organic food by young consumers in an emerging market economy. Journal of Strategic Marketing, 27(6), 540-556. https://doi.org/10.1080/0965254X.2018.1447984

Priyono, \& Ismail, Z. (2012). Teori Ekonomi. Surabaya: Zitama Publisher.

Quadri, S. A. (2020). COVID-19 and religious congregations: Implications for spread of novel pathogens. International Journal of Infectious Diseases, 96, 219-221. https://doi.org/10.1016/j.ijid.2020.05.007

Rahman, N. A. A., Hassan, A., \& Mohammad, M. F. (Eds.). (2020). Halal Logistics and Supply Chain Management in Southeast Asia. Routledge.

Rahman, Z. (2020). Mujāhadah al-nafs among covid 19 patients in quarantine. International Journal of Psychosocial Rehabilitation, 24(1), 5460-5475. Retrieved from https://www.researchgate.net/profile/Mohd_Hilmi_Hamzah/publication/342420605 Muja hadah

Rajab, A. J., Nurdin, M. S., \& Mubarak, H. (2020). Tinjauan Hukum Islam pada Edaran Pemerintah dan MUI dalam Menyikapi Wabah Covid-19. BUSTANUL FUQAHA: Jurnal Bidang Hukum Islam, 1(2), 156-173. https://doi.org/10.36701/bustanul.v1i2.143

Ratten, V. (2020). Coronavirus (Covid-19) and the entrepreneurship education community. Journal of Enterprising Communities: People and Places in the Global Economy. https://doi.org/10.1108/JEC-06-2020-0121

Reardon, J. (2019). Dialogue on Reform in Mainstream Economics and its Implications for the Islamic Economics Discipline. Journal of King Abdulaziz University: Islamic Economics, 32(2), 61-75. https://doi.org/ 10.4197/Islec. 32-2.4

Reinhart, A. K. (1983). Islamic law as Islamic ethics. The Journal of Religious Ethics, 11(2), 186203. Retrieved from https://www.jstor.org/stable/40017705

Rifa'i, I., Irwansyah, F. S., Sholihah, M. A., \& Yuliawati, A. (2020). Dampak dan pencegahan wabah Covid-19: Perspektif Sains dan Islam. Jurnal Lembaga Penelitian dan Pengabdian $\begin{array}{llll}\text { Masyarakat } & (L P 2 M), & \text { Retrieved } & \text { from }\end{array}$ http://digilib.uinsgd.ac.id/30549/1/Karya\%20Tulis\%20Ilmiah Ilyas\%20dkk.pdf Subroto, W. (2020). Analysis on the Regulation on Freedom of Worship in the Case of Covid-19 Pandemic in Indonesia. JL Pol'y \& Globalization, 98, 75. Retrieved from https://heinonline.org/HOL/LandingPage?handle=hein.journals/jawpglob98\&div=14\&id= \&page $=$

Rusiadi, R., Aprilia, A., Adianti, V., \& Verawati, V. (2020). Dampak Covid-19 Terhadap Stabilitas Ekonomi Dunia (Studi 14 Negara Berdampak Paling Parah). JEpa, 5(2), 173-182. Retrieved from http://jurnal.pancabudi.ac.id/index.php/jepa/article/view/904

Salisu, A. A., \& Akanni, L. O. (2020). Constructing a global fear index for the COVID-19 pandemic. Emerging Markets Finance and Trade, 56(10), 2310-2331. https://doi.org/10.1080/1540496X.2020.1785424

Scharmer, C. O., \& Kaufer, K. (2013). Leading from the emerging future: From ego-system to eco-system economies. Berrett-Koehler Publishers.

Sukirno, S. (2009). Mikro Ekonomi. Jakarta: Salemba Empat

Sibarani, M. W. (2016). Analisis Interdependensi Faktor-Faktor Yang Mempengaruhi Penawaran Uang Kartal Di Indonesia (Master thesis, UNIMED). Retrieved from http://digilib.unimed.ac.id/21205/

Silalahi, D. E., \& Ginting, R. R. (2020). Strategi Kebijakan Fiskal Pemerintah Indonesia Untuk Mengatur Penerimaan dan Pengeluaran Negara Dalam Menghadapi Pandemi Covid-19. 
Falah: Jurnal Ekonomi Syariah

Vol. 5 No. 2 (2020)

ISSN (print): 2502-3918 | ISSN (online): 2502-7824

Jesya (Jurnal Ekonomi \& Ekonomi Syariah), $3(2), \quad$ 156-167.
https://doi.10.36778/jesya.v3i2.193

Syaputra, E. (2017). Perilaku Konsumsi Masyarakat Modern Perspektif Islam: Telaah Pemikiran Imam Al-Ghazali dalam Ihya'Ulumuddin. Falah: Jurnal Ekonomi Syariah, 2(2), 144-145. https://doi.org/10.22219/jes.v2i2.5102

Ubaidillah, M., \& Aji, R. H. S. (2020). Tinjauan Atas Implementasi Perpanjangan Masa Angsuran Untuk Pembiayaan Di Bank Syariah Pada Situasi Pandemi COVID-19. Islamic Banking: Jurnal Pemikiran Dan Pengembangan Perbankan Syariah, 6(1), 1-16. https://doi.org/10.36908/isbank.v6i1.159

Uddin, S. J. (2003). Understanding the framework of business in Islam in an era of globalization: a review. Business ethics: a european review, 12(1), 23-32. https://doi.org/10.1111/14678608.00302

Yamali, F. R., \& Putri, R. N. (2020). Dampak Covid-19 Terhadap Ekonomi Indonesia. Ekonomis: Journal of Economics and Business, 4(2), 384-388. http://dx.doi.org/10.33087/ekonomis.v4i2.179

Yezli, S., \& Khan, A. (2020). COVID-19 pandemic: it is time to temporarily close places of worship and to suspend religious gatherings. Journal of travel medicine, 1-2. https://doi.org/10.1093/jtm/taaa065

Yunus, N. R., \& Rezki, A. (2020). Kebijakan Pemberlakuan Lock Down Sebagai Antisipasi Penyebaran Corona Virus Covid-19. Salam: Jurnal Sosial dan Budaya Syar-i, 7(3), 227238. https://doi.org/10.15408/sjsbs.v7i3.15083

Zarqa, M. (2019). Islamic and Conventional Economics-Dialogue and Ethics. Journal of King Abdulaziz University: Islamic Economics, 32(2), 125-135. https://doi.org/10.4197/Islec. 32$\underline{2.10}$ 